\title{
Pro- and prebiotics in pig nutrition - potential modulators of gut health?
}

\author{
B. Zimmermann, E. Bauer and R. Mosenthin \\ Institute of Animal Nutrition, Hohenheim University \\ D-70593 Stuttgart, Germany
}

(Received 29 January 2001; accepted 31 January 2001)

\begin{abstract}
The stressful physiological and environmental conditions experienced in particular by young pigs promote the proliferation of pathogens in the digestive tract. Probiotics, such as lactic acid-producing bacteria, Bacillus spp. and yeast have been reported to improve microbial balance in the gastrointestinal tract through bacterial antagonisms, competitive exclusion and immune stimulation. Prebiotics which include non-digestible oligosaccharides may control or manipulate microbial composition and/or activity, thereby assisting to maintain a beneficial microflora that suppresses through different regulatory mechanisms the growth of pathogens. The combination of probiotics and prebiotics, also referred to as synbiotics, may improve the survival rate of probiotics during their passage through the digestive tract, thus contributing to the stabilization and/or enhancement of the probiotic effects.
\end{abstract}

KEY WORDS: pig, probiotic, prebiotic, non-digestible oligosaccharide, synbiotic, intestine

\section{INTRODUCTION}

In recent years with increasing concern over drug residues in meat products and increased occurence of pathogens resistant against therapeutically used antibiotics in animals and humans, the use of antibiotics as growth promoters has been restricted continuously. For example, a general ban of antibiotics as feed additives was implemented in Sweden and Switzerland in 1986 and 1999, respectively. Consequently, new concepts have been developed aiming to promote animal health and to secure growth performance, feed efficiency and product quality as well. Several naturally occurring compounds have been shown to affect beneficially the composition and activity of the microflora in the gastrointestinal tract of pigs such as organic acids, fermented feed, specific components of dietary fibre and probio- 
tics and prebiotics as well (Jensen, 1998). In the following, alternatives to antibiotics as growth promoters in pigs nutrition will be reviewed including probiotics, prebiotics and the combination of both, also referred to as synbiotics.

\section{DEFINITIONS OF PRO-, PRE- AND SYNBIOTICS}

\section{Probiotics}

According to a widely accepted definition by Fuller (1989) probiotics can be characterised as ,a live microbial feed supplement which beneficially affects the host by improving its intestinal microbial balance". The probiotic effects of lactic acid-producing bacteria have received most attention, probably due to their predominance within the microflora, the historical perception of health-links and, additionally, the observation that they are rarely pathogenic (Kelly, 1998). The microflora in the intestine of livestock in the state of eubiosis is predominantly composed of lactobacilli in addition to different species of bifidobacteria and bacteroidaceae (Gedek, 1987). The species currently being used in probiotic preparations are lactic acid-producing bacteria such as L. bulgaricus, L. acidophilus, L. paracasei, Streptococcus thermophilus, Enterococcus faecium and faecalis, bifidobacteria such as $B$. pseudolongum, $B$. thermophilum, $B$. breve and $B$. bifidum and Bacillus spp. such as $B$. cereus, $B$. toyoi and B. subtilis. Furthermore, fungal probiotics such as Saccharomyces cerevisiae and $S$. boulardi are also commercially available (Durst et al., 1998; Lee et al., 1999).

\section{Mode of action of probiotics}

There are many beneficial claims for probiotics, but it is not always possible to provide sufficient scientific evidence to support them. The potential benefits that can arise from the application of the probiotic concept are growth promotion as well as anti-carcinogenic, anti-pathogenic, anti-allergenic and anti-mutagenic effects. Special attention has been paid to the anti-pathogenic mechanisms which are particularly relevant to young animals and which can be categorised as direct bacterial antagonisms, competitive exclusion and immune stimulation.

Direct bacterial antagonisms are related to the production of various inhibitory substances which are produced by the commensal microflora. These substances include organic acids, hydrogen peroxide, and non-peptide or polypeptide antibiotics, also referred to as bacteriocins. They inhibit the growth of other bacteria including enteric pathogens thus assisting the animal to resist infections. The antimicrobial activities of bacteriocins involve permeabilization of the cell membrane of the target cells (Kelly, 1998). 
According to Kelly (1998) competitive exclusion is the most favoured hypothetical mode of action of probiotics despite the fact that it is difficult to support this hypothesis under in vivo conditions. Various anti-microbial factors such as $\mathrm{pH}$, hydrogen peroxide, bacteriocins, fatty acids and deconjugated bile salts may be involved in the mechanisms that affect competitive exclusion of pathogens (Fuller, 1999).

There is growing evidence that in addition to direct interactions with pathogenic bacteria probiotics may improve disease resistance of the host by modulating systemic and mucosal immunity. In studies with rats oral administration of lactic acid-producing bacteria significantly affected both the systemic and mucosa associated immune response (Perdion and Alvarez, 1992; Famularo et al., 1997).

A recently published review in which the results of probiotic supplementation to piglet diets on growth performance were summarised, showed quite variable results (Forschungsbericht Fachbereich Agrarwirtschaft Soest, 1998). Out of 23 studies, in which lactic acid-producing bacteria $(\mathrm{n}=9)$ or Bacillus spp. $(\mathrm{n}=11)$ or yeast $(\mathrm{n}=3)$ were used as supplements, there were only two studies in which growth performance was significantly improved whereas in some studies even a growth depression was obtained.

There were no significant growth-promoting effects of probiotic supplementation to diets for grower-finisher pigs and the results obtained for sows were equivocal (Forschungsbericht Fachbereich Agrarwirtschaft Soest, 1998).

\section{Prebiotics}

Another approach to protect the host against infections with pathogens would be to improve the beneficial activity of the microflora through specific ingredients in the diet. In recent years, it has been recognised that certain non-digestible oligosaccharides (NDO) specifically promote the proliferation of bifidobacteria (c.g. Hidaka et al., 1986a; Hayakawa et al., 1990). Such NDO escape enzymatic digestion by host enzymes in the gastrointestinal tract and were recently defined as ,non-digestible food ingredients that beneficially affect the host by selectively stimulating the growth and/or activity of one or a limited number of bacteria in the colon" (Gibson and Roberfroid, 1995). Due to the potential of certain NDO to promote a favourable intestinal microflora these authors introduced the term prebiotics.

Physiologically functional oligosaccharides are natural constituents of plants such as legume seeds (Bach Knudsen, 1997) and cereals (Henry and Saini, 1989) consisting of 2-10 sugar units. In addition, NDO can be manufactured under commercial conditions to be used as functional ingredients in feed and food. Table 1 lists some of the NDO used as prebiotics (including their chemical structure and their mode of production). 
TABLE 1

Non-digestible oligosaccharides (NDO) arranged according to their chemical structure

\begin{tabular}{|c|c|c|c|c|}
\hline NDO & $\begin{array}{l}\text { Chemical } \\
\text { structure }\end{array}$ & $\begin{array}{c}\text { Mode } \\
\text { of production }\end{array}$ & Trade name & $\begin{array}{c}\text { Main natural } \\
\text { origin }\end{array}$ \\
\hline Inulin & $\begin{array}{l}\text { Glu (fru) } \\
\mathrm{n}=10-50 ; \beta 1,2\end{array}$ & & Raftiline $^{i j}$ & $\begin{array}{l}\text { Jerusalem } \\
\text { artichoke, } \\
\text { chicory roots, }\end{array}$ \\
\hline $\begin{array}{l}\text { Oligofructose } \\
(\mathrm{FOS})\end{array}$ & $\begin{array}{l}\text { Glu (fru) } \\
n=2-10 ; \beta 1,2\end{array}$ & $\begin{array}{l}\text { Partial enzymatic } \\
\text { hydrolysis of inulin/ } \\
\text { transfructosylation } \\
\text { from saccharose }\end{array}$ & $\begin{array}{l}\text { Raftilose } \\
\text { P95 }\end{array}$ & $\begin{array}{l}\text { onion, garlic, } \\
\text { banana }\end{array}$ \\
\hline $\begin{array}{l}\text { Soybean- } \\
\text { oligosaccharides }\end{array}$ & $\begin{array}{l}\text { Stachyose (fru, } \\
\text { gal, gal, glu) } \\
\text { and raf- finose } \\
\text { (fru, gal, glu) }\end{array}$ & $\begin{array}{l}\text { Extraction from } \\
\text { soyabean whey }\end{array}$ & Soya-oligo & Soyabean \\
\hline $\begin{array}{l}\text { Transgalacto- } \\
\text { oligosaccharides }\end{array}$ & $\begin{array}{l}\text { Glu (gal) } \\
\mathrm{n}=2-5 ; \beta 1,6\end{array}$ & $\begin{array}{l}\text { Trans-galactosylation } \\
\text { of lactose with } \\
\text { Aspergillus oryzae } \\
\beta \text {-galactosidase }\end{array}$ & $\begin{array}{l}\text { Oligomate } 50^{\text {x }} \\
\text { Oligostroop }\end{array}$ & \\
\hline $\begin{array}{l}\text { Isomalto- } \\
\text { oligosaccharides }\end{array}$ & $\begin{array}{l}\text { Glu (Isomaltose) } \\
\mathrm{n}=2-4 ; \alpha 1,6\end{array}$ & $\begin{array}{l}\text { Enzymatic hydrolysis } \\
\text { of starch } \\
\text { Transglucosylation } \\
\text { of maltose }\end{array}$ & $\begin{array}{l}\text { Isomalto-900 } \\
\text { Panorup }^{(x)}\end{array}$ & \\
\hline $\begin{array}{l}\text { Mannan- } \\
\text { oligosaccharides }\end{array}$ & $\begin{array}{l}\text { Mannose }_{n} \\
\mathrm{n}=2-8 ; \alpha 1,6\end{array}$ & $\begin{array}{l}\text { Enzymatic synthesis } \\
\text { from mannose }\end{array}$ & & \\
\hline $\begin{array}{l}\text { Xylo- } \\
\text { oligosaccharides }\end{array}$ & $\begin{array}{l}\text { Xylose } \\
n=2-9 ; \beta I, 4\end{array}$ & $\begin{array}{l}\text { Enzymatic hydrolysis } \\
\text { of xylan }\end{array}$ & Xylo-oligo & \\
\hline Neosugar & $\begin{array}{l}\text { Glu (fru) } \\
n=2-3 ; \beta 1,2\end{array}$ & $\begin{array}{l}\text { Enzymatic synthesis } \\
\text { from saccharose }\end{array}$ & Actilight & \\
\hline Lactulose & Gal, fru; $\beta 1,4$ & Alkali isomerization & $\mathrm{MLS} / \mathrm{P} / \mathrm{C}$ & \\
\hline $\begin{array}{l}\text { Palatinose } \\
\text { condensates }\end{array}$ & $\begin{array}{l}\text { Glu, fru } \\
\text { (Palatinit) } \\
\text { various types } \\
\text { of bonds }\end{array}$ & $\begin{array}{l}\text { Enzymatic synthesis } \\
\text { from saccharose }\end{array}$ & & \\
\hline
\end{tabular}

compiled from data by Delzenne and Roberfroid (1994), Grizard and Barthomeuf (1999) and Van Loo et al. (1995, 1999)

Gal: galactose; glu: glucose; fru: fructose 


\section{Mode of action of prebiotics}

Depending on the type of NDO in the diet, fermentation of NDO may occur in different sections of the digestive tract including stomach, small intestine, caecum and/or colon (Houdijk, 1998; Houdijk ct al., 1998, 1999). As à result, NDO may display bifidogenic characteristics in different sections of the gastrointestinal tract, provided that NDO are fermented exclusively by saccharolytic bacteria. In studies by Houdijk et al. (1999) fermentation of FOS was nearly completed at the end of the small intestine of weaned pigs (initial BW $16 \mathrm{~kg}$ ); the degradation rate exceeded $90 \%$ whereas TOS was fermented at a rate of approximately $30 \%$. Ileal digestibilities of galacto-oligosaccharides range from $57 \%$ in velasse-based diets (Veldman et al., 1993) to $65 \%$ in pea-based diets (Canibe and Bach Knudsen, 1997) and up to nearly 90\% in lupin-based diets (Gdala et al., 1997). Differences in ileal NDO digestibilities may be attributed to different rates of fermentation.

NDO such as FOS and TOS will primarily stimulate the production of acetate and lactate (Wang and Gibson, 1993). Due to the low pKa of these acids, it was found in studies with human subjects that the population of bacteroides, clostridia and fusobacteria in faeces decreased (Gibson et al., 1995). According to Macfarlane and Macfarlane (1993), NDO may increase the barrier effect against infections by enteric pathogens through stimulation of lactic acid production in the small intestine and, particularly, through production of short chain fatty acids in the large intestinc. Table 2 shows the molar ratios of acetate, propionate and butyrate from fermentation of several NDO by mixed faccal bacteria from humans and pigs.

There is growing evidence that NDO are not fermented by saccharolytic bacteria only. Wang and Gibson (1993) claimed that after fermentation of FOS by human faecal inocula succinate, propionate and butyrate could be detected, origina-

TABLE 2

Molar ratios of acctate, propionate and butyrate produced from carbohydrate fermentation by mixed faecal bacteria of humans' and pigs ${ }^{2}$

\begin{tabular}{lccc}
\hline Substratc & Acetate & Propionate & Butyrate \\
\hline Inulin' $^{1}$ & $72 \pm 6$ & $19 \pm 5$ & $8 \pm 2$ \\
Oligofructose $^{1}$ & $78 \pm 4$ & $14 \pm 2$ & $8 \pm 2$ \\
Lactulose $^{1}$ & $81 \pm 5$ & $12 \pm 4$ & $7 \pm 2$ \\
Lactitol $^{1}$ & $85 \pm 4$ & $9 \pm 2$ & $6 \pm 2$ \\
Maltitol' $^{1}$ & $57 \pm 6$ & $26 \pm 6$ & $17 \pm 1$ \\
Mannanoligosaccharide $^{2}$ & $60 \pm 4$ & $30 \pm 6$ & $10 \pm 3$ \\
\hline
\end{tabular}

compiled from data by Wang and Gibson (1993) and Duda et al. (2000) 
ting from direct fermentation of FOS by non-saccharolytic bacteria or indirect fermentation of endproducts produced by lactobacilli and bifidobacteria. In addition, studies by Hartemink and Rombouts (1997) revealed that a significant proportion of different sources of NDO were fermented by other species than bifidobacteria including species such as clostridia, enterobacteria and $E$. coli. None of the NDO that were tested were selective for bifidobacteria (Table 3).

TABLE 3

Bacterial fermentation of non-digestible oligosaccharides

\begin{tabular}{lcccccc}
\hline Bacterial group/specics & FOS & INU & TOS & IMO & LAT & LAC \\
\hline Bacteroides distasonis & + & + & + & + & + & + \\
B. fragilis & + & + & + & + & + & + \\
B. ovatus & + & + & + & + & + & \\
B. thetaiotaomicron & + & + & + & + & & + \\
B. vulgatus & + & + & + & + & + & \\
Bifidobacterium spp. & + & + & + & + & + &,+- \\
Clostrium butyricum & & - & - & - & + & + \\
Cl. clostridioforme &,+- & - & & - & - & + \\
Cl. perfringens &,+- &,-+ &,-+ & + & + & + \\
Cl. ramosum & + & + & & + & + & + \\
Escherichia coli &,-+ & - & + & - &,+- & - \\
Euhacterium lentum & - & - & & - & - & \\
Eu. Limosum & - & - & - & - & - & \\
Lactobacillus acidophilus-group &,+- & + & + &,+- & + & + \\
Lb. Casei &,+- & + & + & - & + & + \\
\hline
\end{tabular}

1 FOS: fructo-oligosaccharides, INU: inulin, TOS: transgalacto-oligosaccharides, JMO: isomaltooligosaccharides, LAT: lactulose, LAC: lactitol (Hartemink and Rombouts, 1997)

\section{Synbiotics}

According to Roberfroid (1998) a synbiotic is defined as ,, mixture of probiotic and prebiotic that beneficially affects the host by improving the survival and the implantation of live microbial dietary supplements in the gastrointestinal tract, by selectively stimulating the growth and/or by activating the metabolism of one or a limited number of health-promoting bacteria".

Several NDO including xylo-oligosaccharides (Suwa et al., 1988), inulo-oligosaccharides (Hidaka et al., 1986b), mannan-oligosaccharides (Kumprecht and Zobac, 1998) as well as TOS, FOS and soyabean oligosaccharides (Rowland, 1992) have been used to promote the proliferation of probiotics. Recent results in piglets revealed synergistic effects of the combination of different probiotics and prebiotics (NDO) in terms of improved growth performance (Kumprecht and Zobac, 
1998), decreased mortality rate (Nousiainen and Setälä, 1993) and increased counts of total anaerobes, aerobes, lactobacilli and bifidobacteria in faecal samples of young pigs (Nemcová et al., 1999). A study with Wistar rats showed 14 days after daily oral administration of over $10^{9}$ live cells of probiotic strains and $/$ or $5 \%(\mathrm{w} / \mathrm{w})$ of oligofructose in the diet, that the composition of the intestinal microflora was almost not affected, except for bifidobacteria. In comparison to the control group, the bifidobacteria live cell numbers in the gut content increased by $0.6 \mathrm{log} \mathrm{cfu} / \mathrm{g}$ in groups of rats receiving $B$. longum, by $1.6 \mathrm{log} \mathrm{cfu} / \mathrm{g}$ in groups fedoligofructose and by $1.4 \log \mathrm{cfu} / \mathrm{g}$ in animals receiving a combination of both (synbiotics) (Bielecka et al., 2000).

\section{CONCLUSIONS}

It is evident that in many cases the enhanced saccharolytic activity in the small intestine of NDO-fed pigs could not be maintained throughout the large intestine due to the fast rate of fermentation of these NDO in the upper tract. Combinations of easily fermentable NDO with slowly fermentable carbohydrates may maintain a constant saccharolytic activity throughout the whole digestive tract.

Pairing NDO and probiotic strains that have the metabolic potential of fermenting the supplied NDO at a competitive rate compared to the indigenous microflora, is likely to be a successful strategy in controlling the intestinal ecosystem. The expected benefits are an improved survival rate during the passage of the probiotic bacteria through the upper intestinal tract and a more efficient implanta-

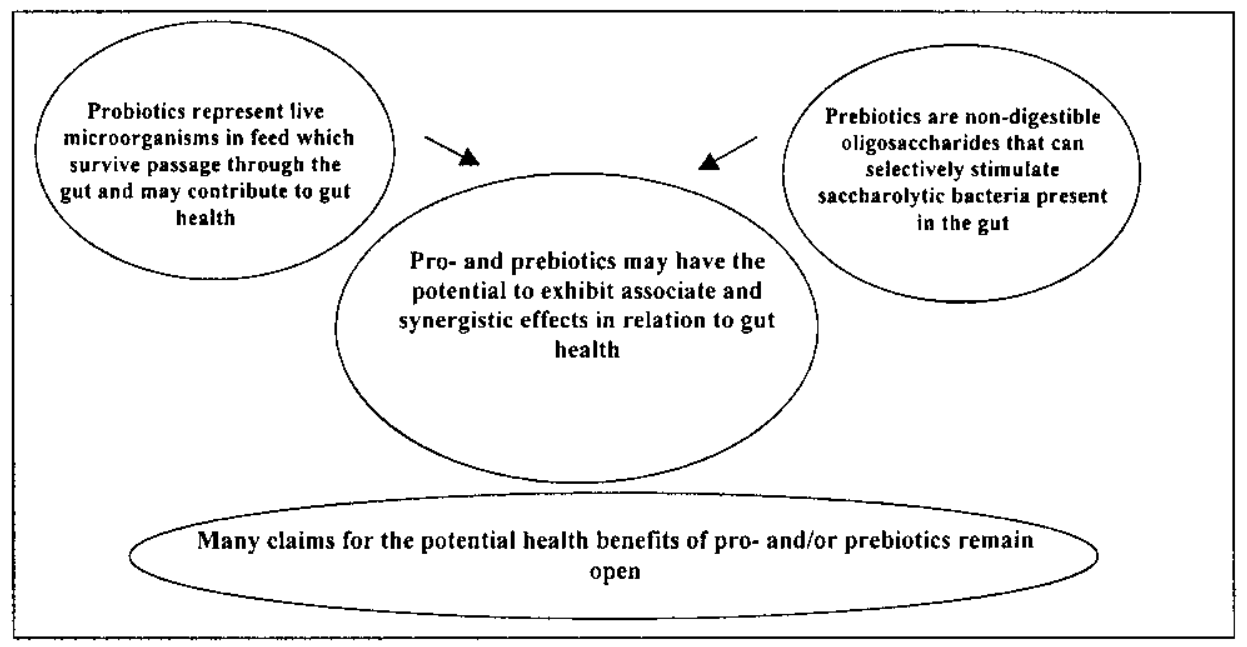

Figure 1. General aspects for the use of pro- and prebiotics in pig nutrition 
tion in the colonic microbiota together with a stimulating effect of the NDO on the growth and/or activity of both the exogenous (probiotic) and endogenous bacteria. In Figure 1 general aspects for the use of pro- and prebiotics in pig nutrition are presented. Future research should be directed towards elucidating the synbiotic mechanisms in more detail.

\section{REFERENCES}

Bach Knudsen K.E, 1997. Carbohydrate and lignin contents of plant materials used in animal fecding. Anim. Feed. Sci. Tech. 67, 319-338

Bielecka M., Biedrzycka E., Juśkiewicz J., 2000. Selection of probiotics and prebiotics for synbiotics and confirmation of their in vivo effectiveness. In: W. Holzapfel (Editor). Functional Food Challenges for the new Millennium. $5^{\text {th }}$ Karlsrube Nutrition Congress, p. 58

Canibe N., Bach Knudsen K.E., 1997. Digestibility of dried and toasted peas in pigs. 1. lleal and total tract digestibilities of carbohydrates. Anim. Feed Sci. Tech. 64, 293-310

Delzenne N.M., Roberfroid M.R., 1994. Physiological effects of non-digestible oligosaccharides. Lebensm.-Wissensch. Technol. 27, 1-6

Duda D., Zacharias B., Drochner W., 2000. Zur Fermentation verschiedener Kohlenhydratpolymere in vitro bei Einsatz von Schweinekot als Inoculum. 112. VDLUFA-Kongress in StuttgartHohenheim: ,Nachhaltige Landwirtschaft”, p. 145

Durst L., Feldner M., Gedek B., Eckel B., 1998. Bacteria as probiotics in sow fecding and piglet rearing. Feed Mag. 9, 356.364

Famularo G., Moretti S., Marcellini S., De Simone C., 1997. Stimulation of immunity by probiotics. In: R. Fuller (Editor). Probiotics. 2. Applications and Practical Aspects. Chapman and Hall, London (UK), pp. 133-161

Forschungsberichte des Fachbereichs Agrarwirtschaft Soest Universität Gesamthochschule Paderborn, 1998. Kritische Betrachtung des Einsatzes von Leistungsförderern in der Tierernäbrung. No. 8. Paderborn (Germany)

Fuller R., 1989. Probiotics in man and animals. J. Appl. Bacteriol. 66, 365-378

Fuller R., 1999. Probiotics for farm animals. In: G.W. Tannock (Editor). Probiotics. A Critical Review. Horizon Scientific Press, Norfolk (UK), pp. 15-22

Gdala J., Jansman A.J.M., Buraczewska L., Huisman J., Van Lecuwen J., 1997. The influence of alpha-galactosidase supplementation on the ileal digestibility of lupin seed carbohydrates and dietary protein in young pigs. Anim. Feed Sci. Tech. 67, 115-125

Gedek B., 1987. Probiotics in animal feeding - effects on performance and animal health. Feed Mag. 2l-24

Gibson G.R., Beatty E.R., Wang X., Cummings J.H., 1995. Selective stimulation of bifidobacteria in the human colon by oligofructose and inulin. Gastroenterology 108, 975-982

Gibson G.R., Roberfroid M.B., 1995. Dietary modulation of the human colonic microbiota: introducing the concept of prebiotics. J. Nutr. 125, 1401-1412

Grizard D., Barthomeuf C., 1999. Non-digestible oligosaccharides used as prebiotic agents: mode of production and beneficial effects on animal and human health. Reprod. Nutr. Develop. 39, $563-588$ 
Hartemink R., Rombouts F.M., 1997. Gas formation from oligosaccharides by the intestinal microflora. In: R. Hartemink (Editor). Proceedings of the International Symposium „Non-Digestible Oligosaccharides: Healthy Food for the Colon?". The Graduate School VLAG, Wageningen Institute of Animal Science, Wageningen (The Netherlands), pp. 57-66

Hayakawa K., Mizutani J., Wada K., Masai T., Yoshihara I., Mitsuoka T., 1990. Effects of soybean oligosaccharides on human faecal flora. Microbiol. Ecol. Health Dis. 3, 293-303

Henry R.J., Saini H.S., 1989. Characterization of cereal sugars and oligosaccharides. Cereal Chem. $66,362-365$

Hidaka H., Eida T., Takizawa T., Tokunaga T., Tashiro Y., 1986a. Effects of fructo-oligosaccharides on intestinal flora and human health. Bifidobact. Microflora 5, 37-50

Hidaka H., Eida T., Hamaya T., 1986b. Livestock feed containing inulo-oligosaccharides and breeding of livestock by using the same. Eur. Pat. Appl. 85109590.1 , Publ. No. 0171026

Houdijk J.G.M, 1998. Effects of non-digestible oligosaccharides in young pig diets. Ph.D. Dissertation, Agricultural University of Wageningen, Wageningen (The Netherlands)

Houdijk J.G.M., Bosch M.W., Verstegen M.W.A., Berenpas H.J., 1998. Effects of dietary oligosaccharides on the growth performance and faecal characteristics of young growing pigs. Anim. Feed Sci. Tech. 71, 35-48

Houdijk J.G.M., Bosch M.W., Tamminga S., Verstegen M.W.A., Berenpas H.J., Knoop H., 1999. Apparent ileal and total tract nutrient digestion by pigs as affected by dietary non-digestible oligosaccharides. J. Anim. Sci. 77, 148-158

Jensen B.B, 1998. The impact of feed additives on the microbial ecology of the gut in young pigs. J. Anim. Feed Sci. 7, Suppl. 1, 45-64

Kelly D, 1998. Probiotics in young and newborn animals. J. Anim. Feed Sci. 7, Suppl. 1, 15-23

Kumprecht I., Zobac P., 1998. Study of the effect of a combined preparation containing Enterococcus faecium M-74 and mannanoligosaccharides in diets for weanling piglets. Czech. J. Anim. Sci. 43, 477-481

Lee Y-K., Nomoto K., Salminen S., Gorbach S. L., 1999. Handbook of Probiotics. John Wiley and Sons, INC, New York, pp. 4-6

Macfarlane G.T., Macfarlane S., 1993. Factors affecting fermentation in the large bowel. Proc. Nutr. Soc. $52,367-373$

Nemcová R., Bomba A., Gancarciková S., Herich R., Guba P., 1999. Study of the effect of Lactobacillus paracasei and fructooligosaccharides on the faecal microflora in weanling piglets. Berl. Mun. Tierärztl. Wochenschr. 112, 225-228

Nousiainen J., Setälä J., 1993. Lactic acid bacteria as animal probiotics. In: S. Salminen, A. von Wright (Editors). Lactic Acid Bacteria. Marcel Dekker, New York, pp. 315-356

Perdion G., Alvarez S., 1992. Probiotics and the immune state. In: R. Fuller (Editor). Probiotics. The Scientific Basis. Chapman and Hall, London (UK), pp. 145-180

Roberfroid M.B., 1998. Prebiotics and synbiotics: concepts and nutritional properties. Brit. J. Nutr. 80, Suppl. 2, S197-S202

Rowland I.R., 1992. Metabolic interactions in the gut. In: R. Fuller (Editor). Probiotics. The Scientific Basis. Chapman and Hall, London (UK), pp 29-54

Suwa Y., Koga K., Fujikawa S., Okazaki M., Irie T., Nakada T., 1988. Lactobacillus bifidus proliferation promoting composition. Eur. Pat. Appl. 87115999.2, Publ. No. 0265970A2

Veldman A., Veen W.A.G., Barug D., van Paridon P.A., 1993. Effect of alpha-galactosides and alpha-galactosidase in feed on ileal piglet digestive physiology. J. Anim. Physiol. Anim. Nutr. 69, $57-65$ 
Van Loo J., Coussement P., De Leenheer L., Hoebregs H., Smits G., 1995. On the presence of inulin and oligof ructose as natural ingredients in the western diet. Crit. Rev. Food Sci. Nutr. $35,525-552$

Van Loo J., Cummings J., Delzenne N., Englyst H., Franck A., Hopkins M., Kok N., Macfarlane G., Newton D., Quigley M., Roberfroid M., Van Vlict T., Van Den Heuvel E., 1999. Functional food propertics of non-digestible oligosaccharides: a consensus from the ENDO project (DGXII AIRII-CT94-1095). Brit. J. Nutr. 81, 121-132

Wang X., Gibson G.R., 1993. Effects of the in vitro fermentation of oligofructose and inulin by bacteria growing in the human large intestine. J. Appl. Bacteriol. 73, 373-380

\section{STRESZCZENIE}

\section{Pro- i prebiotyki w żywieniu świń - modulatory zdrowotności przewodu pokarmowego?}

Stresogenne fizjologiczne i środowiskowe warunki, na które narażone są szczególnie mlode prosięta, przyczyniają się do namnażania organizmów chorobotwórczych w przewodzje pokarmowym. Uznano, że probiotyki, takie jak bakterie produkujące kwas mlekowy, Bacillus spp. i drożdże poprawiają spektrum mikrobiologiczne w przewodzic pokarmowym poprzez antagonizmy miçdzy bakteriami, eliminację na zasadzie wspólzawodnictwa i stymulację odpornościową. Prebiotyki, które zawierają niestrawne oligosacharydy, mogą kontrolować lub zmieniać spektrum i/lub aktywność mikroflory, która poprzez różne mechanizmy regulujące, powstrzymuje rozwój organizmów chorobotwórczych. Kombinacja probiotyków i prebiotyków, nazywana także synbiotykami, może poprawić przeżywanie probiotyków w czasie ich przechodzenia przez przewód pokarmowy, przyczyniając sį̨ do stabilizacji i/lub wzmocnienia działania probiotyków. 